\title{
Back to the Basics: \\ Multilateral Security Cooperation in Northeast Asia and the Neorealist Paradigm
}

\author{
Kim, Jangho \\ (Yonsei University)
}

$\langle$ CONTENTS〉

I. Introduction

II. Neoliberalism vs. Neorealism

III. Anarchy and Cooperation
IV. Northeast Asian Regional Context

V. Conclusion

- Keyword: neorealism, neoliberalism, northeast Asia, realism, liberalism, power politics, balance of power, China, United States, Cold War, international relations theory, eclecticism, multilateral security management, cooperation

\section{【ABSTRACT】}

The new order which is still taking shape in northeast Asia is perplexing the policy makers and the academic community alike. Even well over a decade after the end of the international East-West confrontation, the largely bilateral security arrangements of northeast Asia still remain the lynch pin of security relations in the region, and the global trends of reconciliation and cooperation has yet to bear fruit. Indeed, it can be argued that national strategies, particularly in the area of defence, are more relevant in the region precisely because of the end of the super power contest there. An alternative multilateral structure, voiced by many, which might adequately cope with the interacting interests of the great powers and the greater complexity of the region has yet to emerge.

This paper highlights the prevalence of neorealism for the analysis of the post Cold War northeast Asian regional order in order to pin point the factors that are inhibiting the creation of a multilateral peace mechanism. Because how we perceive a situation or a problem often dictates the solutions that may come about, we need to be thorough in our assessments of the approaches that we use. Recent trends of eclecticism in international relations theory seem only to be confounding 
the already complex and diverse assessments of the situation in northeast Asia. International relations theories exist precisely to minimise confusion, as well as to simplify what would otherwise be confounding. They are the tools which provide coherent and consistent explanations to the behavior of international actors and this is possible because of the theoretical explicitness and the purity which an international relations theory must entail. This paper will show that although northeast Asia may be analysed from the perspective of many different approaches, the neorealist paradigm offers the most fruitful insights. This paper is not a critique of this trend of eclecticism in international relations theory but it hopes to add to the discussion on the debate by reassessing neorealism and its prevalence in the international politics of northeast Asia.

\section{I . Introduction}

Multilateral security initiatives, ${ }^{1,}$ along with the mechanisms that are already in place, throughout the world seem to be promising a new setting for international relations in the years to come. The enlargement and the consolidation of the North Atlantic Treaty Organisation (NATO) in Europe as well as multilateral efforts at peace keeping elsewhere in the world have indicated multilateral endeavors, and the cooperation that it entails, signify a new era in world affairs. Yet, it seems that the jury may still be out on such a conclusion when one considers the state of affairs in northeast Asia. Northeast Asia has not gone through the transition that much of the rest of the world has since the end of the Cold War.

Indeed, it must be said that the "post-Cold War," once thought of as a transitional period of international relations, can rightly be labeled an "era" on its own when

1) For multilateral security initiative, effort, mechanism and/or cooperation, see Robert $O$. Keohane and Joseph S. Nye, Power and Interdependence: World Politics in Transition (Boston: Center for International Affairs, Harvard University, 1977); James N. Rosenau and Hylke Tromp eds., Interdependence and Conflict in World Politics (Hants: Gower Publishing Company Limited, 1989); Gilbert Rozman, Northeast Asia's Stunted Regionalism: Bilateral Distrust in the Shadow of Globalization (Cambridge: Cambridge University Press, 2004); R.J. Barry Jones and Peter Willetts eds., Interdependence on Trial: Studies in the Theory and Reality of Contemporary Interdependence (London: Frances Pinter (Publishers) Limited, 1984); and Helen Milner, "International Theories of Cooperation Among Nations: Strengths and Weaknesses," World Politics, no.3 (1992). 
considering northeast Asia. What then are the characteristics of this era? What is the likelihood of security cooperation among the northeast Asian states during this era? How we approach these crucial questions will determine how we may analise and seek to provide a better understanding of the security situation in northeast Asia. More importantly, because how we perceive a situation or a problem often dictates the solutions that may come about, we need to be thorough in our assessments of the approaches that we use. This paper aims to reassess one of the approaches which has been largely overlooked recently despite its traditional position in international relations theory.

Broadly, the vast differences in the geopolitical setting of the different states in the region seem to suggest two different paradigms; the patterns of economic development and interactions point towards the neoliberalist ${ }^{2}$ school, while at the same time the very real dangers of power transition along with the concern and tension stemming from it, and the remaining Cold War legacies yet to be resolved, appear to support the neorealist paradigm."

This paper discusses these two major approaches, ${ }^{4)}$ which have been widely utilised to explain the international behaviour of the states in northeast Asia. Although numerous other approaches ${ }^{5}$ have been used to provide explanations for the behaviour of states in northeast Asia, neorealism and neoliberalism are the approaches which have withstood the test of time. Recent trends of eclecticism ${ }^{6}$ in international relations theory seem only to be confounding the already complex and diverse assessments of the situation in northeast Asia. International relations theories exist precisely to minimise confusion, as well as to simplify what would otherwise be confounding. They are the tools which provide coherent and consistent explanations to the behavior of international actors and this is possible because of the theoretical explicitness and the purity which an international relations theory must entail. Eclecticism sacrifices this theoretical

2) See Robert O. Keohane and Lisa Martin, "The Promise of Institutionalist Theory," International Security, vol.20, no.1 (1995); and Charles A. Kupchan and Clifford A. Kupchan, "The Promise of Collective Security," International Security, vol.20, no.1 (1995).

3) See Kenneth N. Waltz, Theory of International Politics (Berkeley: Addison-Wesley Publishing Company, Inc., 1979).

4) For a full volume articulation of the debate between neoliberalism and neorealism, see David A. Baldwin ed., Neorealism and Neoliberalism: The Contemporary Debate (New York: Columbia University Press, 1993).

5) For a survey of these approaches, see James E. Dougherty and Robert L. Pfaltzgraff, Jr., Contending Theories of International Relations: A Comprehensive Survey (New York: Addison Wesley Longman, Inc., 2001).

6) See J. J. Suh, Peter J. Katzenstein and Allen Carlson eds., Rethinking Security in East Asia (Stanford: Stanford University Press, 2004). 
explicitness for the sake of policy prescriptions and/or issue oriented studies which are designed to fit the needs of a particular time period. This paper will show that although northeast Asia may be analysed from the perspective of many different approaches, the neorealist paradigm offers the most fruitful insights. This paper is not a critique of this trend of eclecticism in international relations theory but it hopes to add to the discussion on the debate by reassessing neorealism and its prevalence in the analysis of the international politics of northeast Asia.

\section{Neoliberalism vs. Neorealism}

While neorealism has long been used for the purpose of explaining the international behaviour of states, neoliberalism has gained wide acceptance around the world with the emergence of a global market system and the subsequent economic interdependence in the latter half of the twentieth century. As states became more interdependent during the 1960s and the 1970s, with expanding global capital markets and increasing international trade and investment, scholars such as Cooper, Morse, Keohane and Nye theorised that growing economic interdependence would alter the political agenda and military behaviour of states. As economic interdependence grew, it was argued, the utility of military power among states would be reduced, due to the cooperation facilitated by the interdependence. ${ }^{7)}$ In other words, a new liberal critique of neorealism had emerged. This approach stressed the importance of international institutions in reducing the inherent conflict that neorealists assume in an international system. This reasoning is based on the core liberal idea that seeking long term mutual gains is often more rational than maximising individual short term gains. The approach became known as "neoliberal institutionalism" or "neoliberalism" for short.

Neoliberals believe that as modern communications make the world smaller, and as states become economically more interdependent, they cooperate more because it is to their mutual benefit. Neoliberals think, therefore, that northeast Asia will become more stable as a result of this interdependence. For example, they believe that the establishment of multilateral institutions in the region (e.g. Asia-Pacific Economic Cooperation (APEC)) is a positive development which will contribute towards peace and stability. ${ }^{8}$ According to the neoliberal thesis, therefore, the economic vitality of northeast Asia as a whole, and the growing interdependence of the economies of the

7) Ngaire Woods, Explaining International Relations Since 1945 (Oxford: Oxford University Press, 1996), p.14. 
states involved, should enhance cooperation among the states. According to Inoguchi and Stillman, "Asia's undoubted concentration on economic growth has also had a positive impact on the region's security as growth and rising living standards are generally conducive to politico-social stability." ${ }^{9)}$ The general argument of the neoliberalist school is that growing interdependence creates similar economic interests across all states and thus a community of interests which will facilitate cooperation among states. From this perspective, states' preferences in international relations are strongly influenced by domestic economic interests. Implementation of state policies is assumed to be assured by the rational interests that underpin them. ${ }^{10}$ The challenge is to expand the network of economic interdependence, thereby ensuring that prosperity is shared among the participants and the possibility of conflict is reduced. ${ }^{11}$

According to the neoliberal doctrine, economic vitality and the ensuing interdependence should enhance the prospect of cooperation and stability; in other words, the above-mentioned factors would be the ideal conditions for stability and peace. Some political leaders who adhere to the neoliberal doctrine often use interdependence rhetoric to portray interdependence as a natural necessity, as a fact to which policy (and domestic interest groups) must adjust, rather than as a situation partially created by policy itself. They usually argue that conflicts of interest are reduced by interdependence, and that cooperation alone holds the answer to world problems. ${ }^{12)}$

This neoliberal theoretical approach, however, may not fully explain the motives and actions of the states of northeast Asia. States within the region, along with outside states with high stakes in the region, are reluctant to fully espouse the neoliberal paradigm, for two reasons. First, increasing economic interaction and the imperatives of communication not only create interdependence, but also create regional cultural fragmentation and state-centred nationalism, which are mutually reinforcing - a renewed appeal to the citizenry to identify with a national culture and set of values. Indeed, in some degree, nationalism is being used by political elites as a substitute for past ideologies, such as anti-communism. ${ }^{13)}$ Furthermore, instabilities created by the

8) Anthony McGrew and Christopher Brook eds., Asia-Pacific in the New World Order (London: The Open University, 1998), p.90.

9) Takashi Inoguchi and Grant B. Stillman, "Introduction," in Takashi Inoguchi and Grant B. Stillman eds., North-East Asian Regional Security (Tokyo: United Nations University Press, 1997), p.4.

10) Woods (1996), p.14.

11) Inoguchi, "Conclusion: A peace-and-security taxonomy," in Inoguchi and Stillman eds. (1997), p.190.

12) Keohane and Nye (1977), p.7. 
social dislocation resulting from interdependence, or problems with economic development itself are themselves becoming possible sources of conflict between states. Economic interdependence is, therefore, by no means a guarantee for the peaceful resolution of all possible conflicts. The contrary may be the case, where economic and security policies are out of step, or where economic considerations themselves cause tension. ${ }^{14)}$ According to Robert Keohane and Joseph Nye, "rapidly rising economic interdependence can create fear and insecurity among politically important groups...Industries threatened by imports press for governmental protection. Thus, protectionism may increase as economic interdependence becomes more extensive." ${ }^{15}$ Indeed, tensions of this sort have become common in the two of the most important relationships in the region; the Sino-American relations as well as Japanese-American relations.

The second reason for not fully espousing the neoliberal paradigm lies in the persistence of fundamental security problems in the region. The division of both China and Korea await to be resolved, the issue of proliferation of weapons of mass destruction ${ }^{16)}$ needs to be addressed, and resurgent China and Japan are causing concern among all the countries involved in the region. The diversity of issues ${ }^{17)}$ of possible conflicts, therefore, makes it difficult to fully explain the situation in northeast Asia in neoliberal terms. The perspective of neorealism is required to make sense of the international politics of the region.

As the name would suggest, neorealism has its roots in realism, ${ }^{18)}$ which in turn can claim a long tradition. The Chinese strategist Sun Tzu, advised the rulers of states how to survive in an era when war had become a systemic instrument of power for the first time. He showed the rulers how to use power to advance their interests and protect their survival: "realpolitik." At about the same time, Thucydides of Greece, wrote an account of the Peloponnesian War focusing on the relative power of Greek city-states. He wrote that "the strong do what they have the power to do and the weak accept what

13) Robert A. Scalapino, "Major Powers and Future Security in Northeast Asia: The Quest for a New World Order and Northeast Asia," in Major Powers and Future Security in Northeast Asia (Seoul: The Institute for Far Eastern Studies, Kyungnam University, 1995), p.3.

14) Kay Moller, "How Much Insecurity in East Asia," The Pacific Review vol.9, no.1, p.118.

15) Keohane and Nye (1977), p.41.

16) Seong Whun Cheon, "North Korea's Nuclear Program and Its Impact on Northeast Asian Security," in Tae-Hwan Kwak and Edward A. Olsen ed., The Major Powers of Northeast Asia: Seeking Peace and Security (Boulder: Lynne Rienner Publishers, Inc., 1996), p.203.

17) Choon-Kun Lee, "War and Peace on the Korean Peninsula," Korea Military Review, vol.10 (2000).

18) For a definitive characterisation of modern realism, see Hans J. Morgenthau, Politics Among Nations: The Struggle for Power and Peace (Boston: McGraw-Hill, 1985). 
they have to accept." ${ }^{19)}$ There have been numerous advocates of realism since then - its hey-day being from Thomas Hobbes to Hans Morganthau - but the core of realism remains the same: power.

What differentiates neorealists from realists is their departure from realism's pessimistic anthropology. However, neorealists do adhere to three core facets of realism. The first is that international relations are state-centric. The second is that there is a sharp distinction between domestic and international politics, in the sense that there is something about politics between states which makes it very different in kind and form from the politics which occur within states. The third and final assumption is that international relations is a struggle for power and peace. ${ }^{20)}$

Kenneth N. Waltz, a pioneer of neorealism, points out in his influential Theory of International Politics, that "international structure emerges from the interaction of states and then constrains them from taking certain actions while propelling them toward others." For Waltz, a system is the totality formed by the union of parts, a totality enjoying a specific reality which has its own characteristics. The structure depicts the organisation of a system, or the laws of association by which units are combined to form the systemic totality. Processes are simply the patterned relations among units that go on within a system; relations that reflect in varying degrees the constraints imposed by the system's structure. ${ }^{21)}$ The most important feature of the structure is anarchy, i.e. the absence of central rule. Anarchy here refers to a lack of common government in world politics, not to a denial of the fact that an international society - albeit a fragmented one - exists. $^{22)}$

In short, neorealists posit that states act according to the principle of self-help, and each seeks to ensure its own survival. Capabilities define the position of states in the system, and the distribution of capabilities defines the structure of the system. Similarly, changes in the distribution of capabilities stimulate changes in the structure of the system, for example, from a unipolar to a bipolar configuration, or from a bipolar to a multipolar configuration. ${ }^{23)}$ Discernible emphasis on structure is notable throughout the neorealist literature. ${ }^{24)}$

19) Joshua S. Goldstein, International Relations (New York: Longman, 1999), p.54.

20) Alan James, "The Realism of Realism: the State and the Study of International Relations," Review of International Studies, vol.15, no.3, p.217.

21) John Gerard Ruggie, "Continuity and Transformation in the World Polity: Toward a Neorealist Synthesis," World Politics, no.1 (1983), p.264.

22) Robert Axelrod and Robert O. Keohane, "Achieving Cooperation under Anarchy: Strategy and Institutions," World Politics, no.1 (1985), p.226.

23) Charles W. Kegley, Jr. and Eugene R. Wittkopf, World Politics: Trend and Transformation (New York: St. Martin's Press, 1995), p.29. 


\section{Anarchy and Cooperation}

Neorealist theory is very useful in explaining the low degree of cooperation among the states within northeast Asia. It stresses that fear is endemic to the international system. As long as states wish to survive, they must be wary of the threat posed by others and protect themselves against others. Hence, they must be sensitive to their relative position in the distribution of power. It is not cooperation per se that the states are against, but rather it is the condition of insecurity within the system that forces them away from cooperative endeavours. Internationally, the principle of self-help compels states to try to be functionally alike, seeking above all to further their own interests, precisely because mutual dependence remains problematic and, therefore, is a source of vulnerability to states. Economic collaboration takes place, but it is embedded in a competitive political framework. As a result, the international system reflects the relative strengths of the units and their respective capabilities to provide for their own welfare. ${ }^{25)}$ Joseph M. Grieco explains this tendency succinctly:

"States are fundamentally concerned about their physical survival and their political independence, which both result from and depend upon a state's own efforts and thus its relative capabilities. As a result, states want to know what the impact will be of virtually any relationship on their relative defensive capabilities: hence the realist insight that states in anarchy are generally defensive positionalists. Defensive positionalism, in turn, generates a relative-gains problem for cooperation: a state will decline to join, will leave, or will sharply limit its commitment to a cooperative arrangement if it believes that gaps in otherwise mutually positive gains favour partners. ${ }^{26)}$

This situation does not imply the absence of collaboration: collaboration is one of the means that states can employ in pursuit of their interests, some of which will be shared with others. However, it does imply that collaboration occurs "only in ways strongly conditioned by" the structure of anarchy. ${ }^{27)}$ However, even in this inhospitable environment, cooperation sometimes does take place in international relations. The

24) Waltz (1979), pp.70-93.

25) Ruggie, "Continuity and Transformation in the World Polity: Toward a Neorealist Synthesis," World Politics, no.1 (1983), pp.268-269.

26) Helen Milner, "International theories of cooperation among Nations: Strengths and Weaknesses," World Politics, no.3 (1992), p.482.

27) See Waltz (1979), pp.115-116. 
neorealists offer two explanations for cooperation: balance of power and hegemony. The Cold War provides excellent examples to illustrate these two explanations. First, the balance of power theory holds that Western cooperation during the Cold War was the result of balancing to counter the Soviet threat, which provided the incentive for the Western countries to cooperate. ${ }^{28)}$ Free trade was thus in part a result of bipolarity and the Western strategic alliance; allied states were not as sensitive to relative shifts between them in economic benefits that might result from free trade. Moreover, military allies saw relative gains by each other as adding to the overall strength of the alliance. Second, the hegemony theory holds that American power created and maintained the order in the West by offering incentives to the other Western countries to cooperate. ${ }^{29}$ ) Economic openness in international orders may be created and sustained by the concentration of power in one state. Hegemonic powers establish and enforce rules, provide exchange currency, absorb exports, and wield incentives and inducements to encourage other states to remain open. ${ }^{30}$

Critics of neorealism point out that liberal states often practice "co-binding," which is an attempt to tie one another down by locking each other into institutions that mutually constrain one another. They emphasise that the mutual and reciprocal co-binding overcomes the effect of anarchy without producing hierarchy. "By establishing institutions of mutual constraint, co-binding reduces the risks and uncertainties associated with anarchy. It is a practice that aims to tie potential threatening states down into predictable and restrained patterns of behaviour, and it makes unnecessary balancing against such potential threats." ${ }^{31)}$ However, the act of establishing "institutions of mutual constraint" itself is influenced by the overall structure of the system, and, furthermore, "aiming to tie down threatening states by co-binding" is, in actuality, balancing. For example, the most important co-binding institution in the West was, and still is, NATO. The foremost reason for the development of this institution was to counter-balance the Soviet threat.

These two paradigms are both very useful analytic tools. However, because of the very clear evidence of balance of power politics in northeast Asia, as well as lack of cooperation between the major actors, the neorealist paradigm seems most fitting.

28) Daniel Deudney and G. John Ikenberry, "The nature and sources of liberal international order," Review of International Studies, vol.25, no.2, pp.179-180.

29) Ibid., pp.179-180.

30) Ibid., p.190.

31) Ibid., pp.182-183. 


\section{Northeast Asian Regional Context}

Northeast Asia is a paradigm case for the neorealist paradigm. Power politics ${ }^{32)}$ prevail in this region because of its delicate and fluid geopolitical configuration, potential change in the regional balance of power, ${ }^{33)}$ as well as security liabilities still remaining to be resolved. This is not only for the reasons already mentioned, but also because of the two inherent features of the region; highly centralised governments within unitary states, and the absence of effective regional institutions. The states of the region, particularly those with a Confucian political heritage (Korea, China and, to some extent, Japan), exhibit high levels of centralisation, as they were among the first in establishing such form of governance. Not surprisingly, therefore, states, not international institutions have taken centre stage.

The lack of fully institutionalised democratic practices has also meant that nationalism has been a crucial factor in this phenomenon, and this nationalism has been in turn reinforced by the conflictual history ${ }^{34)}$ of the region which has proven to be a bigger obstacle than most governments have realised. A common sense of history is not shared in northeast Asia to the degree it is in Europe. ${ }^{35)}$ If anything is shared, it is bilateral antagonisms which reflect the many separate relationships.

Regime building within the region, therefore, has been, and probably will remain, a

32) John J. Mearsheimer, The Tragedy of Great Power Politics (New York: W.W. Norton \& Company, Inc., 2001), p.373.

33) The fundamental geopolitical interests of the major powers in the region in general, and with the Sino-American relations in particular, simply does not provide a fertile foundation for the stability of the current regional balance of power. The United States strategic objective in northeast Asia is as simple as it is difficult to achieve and maintain: prevent the rise of a potentially hegemonic power. The same goal applies for the European theatre. The United States has fought World War I and II, as well as the Korean War, among others to achieve this goal. The American geopolitical objective of preventing a hegemonic power to arise in Pacific Asia has remained constant since the acquisition of the Philippine Islands. The complexity of the situation arises from both the speculations concerning China's aspirations as well as its actual and latent power. Much will depend on how the United States manages to exercise its geopolitical interest in this setting.

34) Chung-min Lee, "What Security Regime in North-East Asia?," Adelphi Papers, vol.276, p.6.

35) For articulations of the state of international affairs in Europe and how it compares with northeast Asia, see Wolgang F. Schlor, "German Security Policy: An Examination of the Trends in German Security Policy in a New European and Global Context," Adelphi Papers, vol.277 (1993); Robert E. Hunter, The European Security and Defense Policy: Nato's Companion-or Competitor? (Santa Monica: Rand, 2002); Vassiliki N. Koutrakou ed., Contemporary Issues and Debates in EU Policy: The European Union and International Relations (Manchester: Manchester University Press, 2004); Samuel Kim ed., The International Politics of Northeast Asia (Oxford: Rowman \& Littlefield Publishers, Inc., 2004); and Rozman (2004). 
difficult task. A set of rules, norms and procedures of international affairs required for the existence of international regimes is difficult to establish and even more difficult to enforce. Confidence building measures have been attempted, but confidence building takes time, and crises will certainly not wait until the institutions are at hand to defuse them. ${ }^{36)}$ Furthermore, the situation in northeast Asia does not provide a foundation on which international regimes could flourish, because of the still emerging, but not yet settled, power configuration between the regional players. International regimes only codify and normalise existing power relations, they do not negate the effect of power. ${ }^{37}$ A regime may be effective in maintaining a certain status quo, but generally it has little capability for affecting the process of fundamental power shift, or dealing with the conflicts which may stem from such a process.

Northeast Asia confronts an increasingly interdependent yet fragmenting international framework that is posing serious challenges to the states of the region. Northeast Asia' s adjustment following the Cold War has been affected by the way in which the Cold War camouflaged indigenous tensions, and the extent to which a local variant of the Cold War had taken root. Asymmetry of power resources, diversity of political regimes, regional disputes as well as socialism, still exist in northeast Asia. ${ }^{38)}$ All these "contending issues" are making consensus building, a natural precursor to multilateralism, a formidable task. Furthermore, northeast Asia has to come to terms with the collapse of the central organising principle ${ }^{39)}$ in strategic affairs; conflicting pressures for new security architectures; a newly emerging regional balance of power; and apprehension about the stability of a continuing U.S. role ${ }^{40)}$ in the region. If history is any indicator, these changes suggest that systemic adjustments in international security arrangements would be necessary in order to ensure stability. ${ }^{41)}$

During the Cold War, unlike in the Europe Atlantic region, there was neither a single threat commonly perceived nor a multilateral structure of security cooperation

36) Inoguchi, "Conclusion: A peace-and-security taxonomy," in Inoguchi and Stillman eds. (1997), p. 205 .

37) Goldstein (1999), p.102.

38) Andrew Mack, "Security Cooperation in Northeast Asia: Problems and Prospects," Journal of Northeast Asian Studies, vol. XI , no.2, p.28.

39) The central organising principle was the East-West conflict of the Cold War which dictated and restricted foreign policy for the states in northeast Asia in general and South Korea and Japan in particular.

40) G. John Ikenberry and Michael Mastanduno eds., International Relations Theory and the Asia Pacific (New York: Columbia University Press, 2003), p.424.

41) William J. Murphy, "Power Transition in Northeast Asia: U.S.-China Security Perceptions and the challenges of Systemic Adjustment and Stability," Journal of Northeast Asian Studies, vol. XIII , no.4 (1994), p. 63. 
throughout northeast Asia. Northeast Asia had no such multilateral structure of security and political cooperation as the NATO or the Conference on Security and Cooperation in Europe (CSCE). Northeast Asian security depended on the network of bilateral arrangements centered on the United States and the Soviet Union.

Many countries in the region are uneasy over the uncertainty involving new multilateral security arrangements that might be forged. In northeast Asia, most of the key security issues and arrangements are bilateral. The bilateral issues include the two Koreas, China and Taiwan, and the dispute between Japan and Russia over the "Northern Territories." Most regional states see the solution to these problems lying primarily, if not exclusively, in the relevant bilateral relationships. Furthermore, the United States, along with her allies, fear that multilateral security institutions would somehow risk diminishing U.S. influence in the region. ${ }^{42)}$

Adding to the fluid northeast Asian balance of power is the steady and persistent rise of Chinese economic and military strength, ${ }^{43)}$ along with the considerable strength from the size of its territory and population, as well as from its cultural cohesion and history. ${ }^{44)}$ China's humiliation by the great powers during the past century underlay its goal of building a powerful, modern state. The Chinese have a very strong sense of who they are, what China has been, and what it should become in the future. The Proponents of the "China threat" theory ${ }^{45)}$ argue that this is illustrated by China's irredentist behavior as well as its inclination to adhere to a worst-case view of how

42) Andrew Mack, "Security Cooperation in Northeast Asia: Problems and Prospects," Journal of Northeast Asian Studies, vol. XI, no.2, p.29.

43) See William H. Overholt, The Rise of China: How Economic Reform is Creating a New Superpower (New York: W.W. Norton \& Company, Inc., 1993); Richard K. Betts, "Wealth, Power and Instability: East Asia and the United States after the Cold War," International Security, vol.18, no.3, pp.34-77; and Ivan Eland, "Is Chinese Military Modernization a Threat to the United States?," Policy Analysis, no.465 (2003), pp.1-14.

44) See Herbert Yee and Ian Storey eds., The China Threat: Perceptions, Myths and Reality (London: RoutledgeCurzon, 2002).

45) For articulations of the "China Threat" theory see Michael E. Brown, Owen R. Cote, Jr., Sean M. Lynn-Jones and Steven E. Miller eds., The Rise of China (Cambridge: The MIT Press, 2000); Denny Roy, “The 'China Threat' Issue: Major Arguments," Asian Survey, vol.36, no.8, pp.758-771; Aaron L. Friedberg, "Ripe for Rivalry: Prospects for Peace in a Multipolar Asia," International Security, vol.18, no.3, pp.5-33; Charles A. Kupchan, "After Pax Americana: Benign Power, Regional Integration, and the Sources of Stable Multipolarity," International Security, vol.23, no.2 (1998), pp.62-66; Gerald Segal, "East Asia and the Constrainment of China," International Security, vol.20, no.4 (1996), pp.107-135; Douglas T. Stuart and William Tow, "A U.S. Strategy for the Asia-Pacific: Building a Multipolar Balance-of-Power System in Asia," Adelphi Paper, no.229 (London: International Institute for Strategic Studies [IISS], 1995); Richard Bernstein and Ross H. Munro, The Coming Conflict with China (New York: Random House Inc., 1998); Gerald Segal, "East Asia and the Constrainment of China," 
others might be planning to undercut its power and interests. ${ }^{46)}$ These evidences suggest that China may well be the high church of realpolitik in the post Cold War world. ${ }^{47)}$

Many have argued that China's emphasis on economic development and the consequent interdependence with the other states of the region will broaden the foundation for peace and prosperity in northeast Asia. ${ }^{48)}$ Furthermore, it is argued that, because China's military hardware is outmoded and because of the ever-widening gap between the military technology ${ }^{49)}$ of the United States and China, China is in no way a peer competitor of the United States. ${ }^{50)}$ Both economic and military data show that China is nowhere close to threatening the global position of the United States yet, she has, nevertheless, been encroaching upon American influence ${ }^{51)}$ in northeast Asia. ${ }^{52)}$ Whether this encroachment signals a more profound change in the overall balance of power is a question that merits further study. However, it seems certain that it adds uncertainty to the already volatile situation in the region thereby contributing to the tendency of short-term power balancing.

Given the fact that China traditionally has been the preeminent regional power for most of the regions history, China's attempt to throw her weight around in northeast Asia is normal and expected. It has been precisely this prospect upon which much of the policies of the major players of northeast Asia are contingent. Because rapid growth often produces social turmoil, because accommodation is tricky, and because China is emerging on to the scene in a "fluid" regional environment lacking most of the elements that can mitigate conflict, the future of East Asian international politics seems especially problematic. ${ }^{53)}$ This outlook is based on the two assumptions that growing Chinese power could produce a dangerous security dilemma leading to a region wide

International Security, vol.20, no.4 (1996), pp.107-135; Bill Gertz, The China Threat: How the People's Republic Targets America (Washington D.C.: Regnery Publishing, Inc., 2000); Ted C. Fishman, China Inc.: How the Rise of the Next Superpower Challenges America and the World (New York: Scribner, 2005); Yee and Storey eds. (2003); and Warren I. Cohen, America's Response to China: A History of Sino-American Relations (New York: Columbia University Press, 2000), pp.26-54.

46) See Gertz (2000).

47) William T. Tow, Asia-Pacific Strategic Relations: Seeking Convergent Security (Cambridge: Cambridge University Press, 2001), p.13.

48) Evan S. Medeiros and M. Taylor Fravel, "China's New Diplomacy," Foreign Affairs, vol.82, no.6, pp.22-35.

49) Choongang Ilbo, October 31, 2003.

50) Ivan Eland, "Is Chinese Military Modernization a Threat to the United States?," Policy Analysis, no. 465 (2003), pp.1-14.

51) See Joseph S. Nye, Jr., Soft Power: The Means to Success in World Politics (New York: Public Affairs, 2004).

52) New York Times, December 3, 2003. 
arms race, ${ }^{54)}$ and that the expansion of Chinese security interests could conflict with the established network of regional security arrangements. ${ }^{55)}$

What complicates things further is that the United States has been seen by many Chinese as an aggressive and powerful force in international affairs. Some Chinese claim that the United States, has, all along, wanted to establish a security regime that would be dominated by itself, and to make the issue of security an excuse for interfering in the other countries' internal affairs. ${ }^{56)}$ The end of the Cold War system has brought to the fore the Chinese fear ${ }^{57)}$ of a unipolar situation dominated by the United States. The relations between the United States and China have often been very unstable and therefore unpredictable, and much will depend on how they decide to manage their ambivalent relationship. The American strategy for northeast Asia is to prevent any single power from dominating the region. ${ }^{58}$ Thus, coping with a rising China is an important diplomatic challenge for Washington.

It is important to recognise that America's post World War II dominance in northeast Asia, though justified as a deterrent to Soviet ambitions, had the equally important function of keeping apart the traditional regional rivals - Russia, Japan and China. ${ }^{59)}$

53) Gideon Rose, "Neoclassical Realism and Theories of Foreign Policy," World Politics, vol.51, no.1, p.171.

54) Dong-a Ilbo, January 28, 2004.

55) William J. Murphy, "Power Transition in Northeast Asia: U.S.-China Security Perceptions and the Challenges of Systemic Adjustment and Stability," Journal of Northeast Asian Studies, vol. XIII , no.4 (1994), p. 64.

56) Song Yimin, "China and North-East Asia's Regional Security," in Inoguchi and Stillman eds. (1997), p.45.

57) Muthiah Alagappa, "Introduction: Predictability and Stability Despite Challenges," in Muthiah Alagappa ed., Asian Security Order: Instrumental and Normative Features (Stanford: Stanford University Press, 2003), p.6.

58) Three overarching goals are evident when one looks to analise America's interests in northeast Asia. First, the United States has remained concerned with maintaining a balance of power in the region that is favourable to American interests. This implies that U.S. policy opposes efforts at domination of the region by a power or a group of powers. Second, the United States has endeavoured to advance its economic interests in the region through involvement in economic development and expand U.S. trade and investment. A third major goal, centred on American culture and values, has involved efforts to foster democracy, human rights, and other trends deemed progressive by American. Of the three goals, the first is the most important in that it sets the foundation for the other two goals. And it is this goal which has been labelled a "vital interest" by many American officials. For further articulation, see Robert G. Sutter, The United States and East Asia: Dynamics and Implications (Oxford: Rowman \& Littlefield Publishers, Inc., 2003).

59) See Kenneth N. Waltz, "Structural Realism after the Cold War," in G. John Ikenberry ed., America Unrivalled: The Future of the Balance of Power (Ithaca: Cornell University Press, 2002), pp.29-67. 
Tokyo and Beijing are aware that America's mood of retrenchment would weaken the buffer that stood between them and that there is no apparent successor to play this role. Significant in the long-term future of the region is the intensification of Japanese assertiveness, repressed for decades by reliance on American military might. This has been a major concern on the part of Japan's neighbours, as a more powerful Japan may significantly alter the northeast Asian strategic landscape. Japanese economic ambitions and a growing willingness to assert political independence are likely to be reflected in its policies toward China, Russia and Southeast Asia. ${ }^{60)}$ The Americans realise that a substantial weakening of their military position in South Korea would be taken in Tokyo as a sign of US withdrawal from Asia and would encourage an independent rearmament of Japan. Even without any reason for the speculation of American military withdrawal from the region, Japanese Constitutional amendments are under way which would strengthen its military considerably, possibly including offensive capabilities. ${ }^{61}$

An added cause of tension in northeast Asia arises from the divisions of both China and the Korean peninsula. Already possessing formidable armed forces, all four concerned states are constantly upgrading their military capabilities. The high level of hostility between North and South Korea has continued, casting a shadow over the region as a whole. Relations between China and Taiwan remain strained because of China's long-held aim to restore Taiwan to Chinese rule. Even the casual observer can note the discrepancy between the optimistic rhetoric on the one hand, and the rising defence expenditure, the number of potential and acute trouble spots, apprehension about China, and repeated calls from the region to the U.S. to maintain her military presence, on the other. ${ }^{62)}$

Given this fluid situation, the countries of northeast Asia seem largely indifferent to the possibility of enhancing military stability in the region through a multilateral security approach. It seems unlikely, therefore, that international institutions would have great effect in minimising the potential for conflict in the region by reducing the uncertainties of the changing power configuration. ${ }^{63)}$ All this is not to imply that the

60) Richard W. Mansbach, "The New Order in Northeast Asia: A Theoretical Overview," in Manwoo Lee and Richard W. Mansbach eds., The Changing Order in Northeast Asia and the Korean Peninsula (Seoul: Seoul Computer Press, 1993), p.39.

61) Choongang Ilbo, August 4, 2005.

62) Kay Moller, "How Much Insecurity in East Asia," The Pacific Review, vol.9, no.1, p.115.

63) See Kenneth N. Waltz, Man, the State and War (New York: Columbia University Press, 1954); Waltz (1979); John Gerard Ruggie, "Continuity and Transformation in the World Polity: Toward a Neorealist Synthesis," World Politics, no.1 (1983); James N. Rosenau and Hylke Tromp eds., Interdependence and Conflict in World Politics (Hants: Gower Publishing Company Limited, 1989); R.J. Barry Jones and Peter Willetts eds. Interdependence on Trial: Studies in the Theory 
spectre of war looms over the horizon, nor that potentially significant tensions cannot be diffused. Only that the search for a common multilateral security framework in northeast Asia, however well-intentioned or designed, faces a number of fundamental challenges and that an approach capable of producing realistic measures to prevent and contain possible conflicts must be brought in to service.

\section{Conclusion}

As the title indicates, this paper is an attempt to reassess one of the traditional international theories against the backdrop of what seems to be an overflow of unstructured approaches in the analysis of northeast Asian international affairs. Due to the abundance of eclectic approaches themselves, and the possible variations stemming from them, theoretical explicitness seems to be suffering in what already was a relatively theory poor field that is the international relations studies. A critique of eclecticism does not have a place in this paper because it would be impossible to mention all the variations of that approach in a single paper as well as because it is simply not an intention of this paper to do so. Rather, this paper accepts all that the current trend is doing to enrich the study of international studies, but would like to point out that, contrary to the belief of some recent scholarly works, neorealism is still very much useful and prevalent to the study of northeast Asian affairs.

It seems that neorealism is not only useful in the analysis of northeast Asian security relations, but in fact very much a necessary tool. The post-Cold War era brought to the fore a competition for regional influence among the great powers in a region formerly dominated by the Cold War's ideological conflict. It can be argued that national strategies, particularly in the area of defence, are more relevant in the region precisely because of the end of the super power contest there. Given the lack of a common security denominator, divergent perceptions of threat, and deeply ingrained historical legacies, the development of multilateral regional security mechanisms seem especially problematic. If history is any indicator, great powers have never tended to entrust their interests in an international institution nor saw eye to eye with multilateral approaches in conducting their security policies. The mere presence of the four largest powers in the world makes northeast Asia a prime target of balance of power politics. The United

and Reality of Contemporary Interdependence (London: Frances Pinter (Publishers) Limited, 1984); and Robert O Keohane ed. Neorealism and its Critics (New York: Columbia University Press, 1986). 
States and China found that they have no overarching motive for strategic cooperation despite their growing economic ties. China seems poised to expand its strategic reach and regain its traditional prominence in northeast Asia. As for the United States, the continued ability to intervene in the northeast Asian region rests heavily on its forward-based military presence in Japan and South Korea and its guarantees of protection to South Korea, Japan, and to some extent, Taiwan.

An alternative structure which might adequately cope with the interacting interests of the great powers and the greater complexity of the region has yet to emerge. Northeast Asia faces challenges both old and new, including national divisions, resumption of traditional rivalries and an on-going competition for influence in the region. More than any other region, northeast Asia most likely will be a theatre of great power politics involving traditional methods of power balancing. Therefore, it seems the utility of the neorealist paradigm in explaining the behavior of the states of northeast Asia has not passed its use-by date. 


\section{REFERENCES}

Alagappa, Muthiah ed. Asian Security Order: Instrumental and Normative Features. Stanford: Stanford University Press, 2003.

Alagappa, Muthiah ed. Asian Security Practice: Material and Ideational Influences. Stanford: Stanford University Press, 1998.

Baldwin, David A. ed. Neorealism and Neoliberalism: The Contemporary Debate. New York: Columbia University Press, 1993.

Bernstein, Richard and Ross H. Munro. The Coming Conflict with China. New York: Random House Inc., 1998.

Brown, Michael E., Owen R. Cote, Jr., Sean M. Lynn-Jones and Steven E. Miller eds. The Rise of China. Cambridge: The MIT Press, 2000.

Cohen, Warren I. America's Response to China: A History of Sino-American Relations. New York: Columbia University Press, 2000.

Dougherty, James E. and Robert L. Pfaltzgraff, Jr., Contending Theories of International Relations: A Comprehensive Survey. New York: Addison Wesley Longman, Inc., 2001.

Fishman, Ted C. China Inc.: How the Rise of the Next Superpower Challenges America and the World. New York: Scribner, 2005.

Gertz, Bill. The China Threat: How the People's Republic Targets America. Washington D.C.: Regnery Publishing, Inc., 2000.

Goldstein, Joshua S. International Relations. New York: Longman, 1999.

Handel, Michael. Weak States in the International System. London: Frank Cass and Company Limited, 1981.

Holbraad, Carsten. Middle Powers in International Politics. Hong Kong: The Macmillan Press Ltd., 1984.

Hong, Yung-lee and Chong-wook Chung eds., Korean Options in a Changing International Order. Berkeley: The Regents of the University of California, 1993.

Hughes, Barry B. Continuity and Change in World Politics: Competing Perspectives. Upper Saddle River: Prentice-Hall, Inc., 1997.

Hunter, Robert E. The European Security and Defense Policy: Nato's Companion-or Competitor? Santa Monica: Rand, 2002.

Ikenberry, G. John ed. America Unrivalled: The Future of the Balance of Power. Ithaca: Cornell University Press, 2002. 
Ikenberry, G. John and Michael Mastanduno eds. International Relations Theory and the Asia Pacific. New York: Columbia University Press, 2003.

Inoguchi, Takashi and Grant B. Stillman eds. North-East Asian Regional Security. Tokyo: United Nations University Press, 1997.

Jones, R.J. Barry, and Peter Willetts eds. Interdependence on Trial: Studies in the Theory and Reality of Contemporary Interdependence. London: Frances Pinter (Publishers) Limited, 1984.

Kegley, Charles W. Jr. and Eugene R. Wittkopf. World Politics: Trend and Transformation. New York: St. Martin' s Press, 1995.

Keohane, Robert O. and Joseph S. Nye, Power and Interdependence: World Politics in Transition. Boston: Center for International Affairs, Harvard University, 1977.

Keohane, Robert O. ed. Neorealism and its Critics. New York: Columbia University Press, 1986.

Kim, Samuel ed. The International Politics of Northeast Asia. Oxford: Rowman \& Littlefield Publishers, Inc., 2004.

Kim, Woosang ed. Northeast Asian Regional Security Order and Strategic Calculus on the Taiwan Straits. Seoul: Yonsei University Press, 2003.

Koutrakou, Vassiliki N. ed. Contemporary Issues and Debates in EU Policy: The European Union and International Relations. Manchester: Manchester University Press, 2004.

Kwak, Tae-Hwan and Edward A. Olsen eds. The Major Powers of Northeast Asia: Seeking Peace and Security. Boulder: Lynne Rienner Publishers, Inc., 1996.

Lee, Manwoo and Richard W. Mansbach eds. The Changing Order in Northeast Asia and the Korean Peninsula. Seoul: Seoul Computer Press, 1993.

McGrew, Anthony and Christopher Brooks eds. Asia-Pacific in the New World Order. London: The Open University, 1998.

Mearsheimer, John J. The Tragedy of Great Power Politics. New York: W.W. Norton \& Company, Inc., 2001.

Morgenthau, Hans J. Politics Among Nations: The Struggle for Power and Peace. Boston: McGraw-Hill, 1985.

Nester, William. International Relations: Geopolitical and Geoeconomic Conflict and Cooperation. New York: HarperCollins College Publishers, 1995.

Nye Jr., Joseph S. Soft Power: The Means to Success in World Politics. New York: Public Affairs, 2004.

Olsen, Edward A. eds., The Major Powers of Northeast Asia: Seeking Peace and Security. 
Boulder: Lynne Rienner Publishers, Inc., 1996.

Overholt, William H. The Rise of China: How Economic Reform is Creating a New Superpower. New York: W.W. Norton \& Company, Inc., 1993.

Rapkin, David P. ed. World Leadership and Hegemony. London: Lynne Rienner Publishers, Inc., 1990.

Rosenau, James N. and Hylke Tromp eds. Interdependence and Conflict in World Politics. Hants: Gower Publishing Company Limited, 1989.

Rozman, Gilbert. Northeast Asia's Stunted Regionalism: Bilateral Distrust in the Shadow of Globalization. Cambridge: Cambridge University Press, 2004.

Scalapino, Robert A. Major Powers and Future Security in Northeast Asia. Seoul: The Institute for Far Eastern Studies, Kyungnam University, 1995.

Suh, J. J., Peter J. Katzenstein and Allen Carlson eds., Rethinking Security in East Asia. Stanford: Stanford University Press, 2004.

Sutter, Robert G. The United States and East Asia: Dynamics and Implications. Oxford: Rowman \& Littlefield Publishers, Inc., 2003.

Tow, William T. Asia-Pacific Strategic Relations: Seeking Convergent Security. Cambridge: Cambridge University Press, 2001.

Waltz, Kenneth N. Man, the State and War. New York: Columbia University Press, 1954.

Waltz, Kenneth N. Theory of International Politics. Berkeley: Addison-Wesley Publishing Company, Inc., 1979.

Wight, Martin, Hedley Bull and Carsten Holbraad eds. Power Politics. Leicester: Leicester University Press, 1978.

Woo, Chul Koo and Jinwoo Choi eds. Korea and China in the New Global System. Seoul: Korean Association of International Studies, 2002.

Woods, Ngaire. Explaining International Relations Since 1945. Oxford: Oxford University Press, 1996.

Yee, Herbert and Ian Storey eds. The China Threat: Perceptions, Myths and Reality. London: RoutledgeCurzon, 2002. 